\title{
Notes on the spider genus Acontius, with a description of two new species from Guinea and Burundi (Aranei: Cyrtaucheniidae)
}

\author{
Заметки по паукам рода Acontius с описанием двух новых видов \\ из Гвинеи и Бурунди (Aranei: Cyrtaucheniidae)
}

\author{
Sergei L. Zonstein

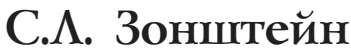

Steinhardt Museum of Natural History, Tel-Aviv University, 69978 Tel-Aviv, Israel. Email: znn@post.tau.ac.il

KEY WORDS: Taxonomy, spiders, Araneae, Mygalomorphae, Africa.

КЛЮЧЕВЫЕ СЛОВА: Таксономия, пауки, Araneae, Mygalomorphae, Африка.

ABSTRACT. Acontius nimba sp.n. (O'o) and $A$. kiriba sp.n. $\left(\bigcirc^{7}+\right)$ are described from Guinea and $\mathrm{Bu}-$ rundi, respectively. Due to the similar structure of the male palp, the former resembles the Guinean A. stercoricola (Denis, 1955), while the latter looks to be related to the Eastern Congolese A. machadoi (Lawrence, 1938). However, both new species differ from their relatives by colouration, spination of legs IIV, and the structural details of the tegulum and embolus.

How to cite this article: Zonstein S.L. 2018. Notes on the spider genus Acontius, with a description of two new species from Guinea and Burundi (Aranei: Cyrtaucheniidae) // Arthropoda Selecta. Vol.27. No.3. P.219-226. doi: 10.15298/arthsel. 27.3.04

PЕЗЮМЕ. Acontius nimba sp.n. $\left(\bigcirc^{7}\right)$ и $A$. kiriba sp.n. $\left(\sigma^{7}+\right)$ описываются соответственно из Гвинеи и Бурунди. Структура пальпы самца сближает первый из них с гвинейским A. stercoricola (Denis, 1955), а второй - с восточно-конголезским A. machadoi (Lawrence, 1938); однако оба новых представителя рода отличаются от близких видов окраской, вооружением ног I-IV, а также деталями строения тегулума и эмболюса.

\section{Introduction}

The spider genus Acontius Karsch, 1879 is now known to encompass 10 species [WSC, 2018]. The majority of the hitherto known Acontius spp., except two of them (see Schiapelli, Gerschman de Pikelin, 1962; Raven, 1985), have not been studied and depicted since their original descriptions. Almost all registered species, with the single exception of $A$. africanus (Simon, 1889), remain known only from either males or females (5 and 4 , respectively). The shape of the embolus or the structure of the spermathecae are illustrated for six known species of the genus [Lessert,
1938, fig. 6; Roewer, 1953, figs 12D, 13D; Denis, 1955, figs 2-3; Schiapelli, Gerschman, 1962, fig. pl. IV, fig. 1; Raven, 1985, fig. 201]. Taking in view all the above, the genus should not be considered sufficiently studied.

The present study is based on an examination of spider samples containing cyrtaucheniids deposited in the collections of the Musée Royal de l'Afrique Centrale (Tervuren, Belgium); the Senckenberg Naturmuseum (Frankfurt, Germany) and the Steinhardt Museum of Natural History (Tel-Aviv, Israel). This examination has revealed two new species of Acontius. Their diagnoses and descriptions are provided below.

\section{Material and methods}

Specimens from the following spider collections were studied: MRAC - Musée Royal de l'Afrique Centrale; SMF — Senckenberg Naturmuseum; SMNH - Steinhardt Museum of Natural History. Photographs were taken using a Zeiss Discovery V20 stereomicroscope with a Canon PowerShot G9 camera, and a Canon 500D digital camera with a $100 \mathrm{~mm}$ Canon macro lens, and prepared using Helicon Focus 6.3.2 Pro (http://www.heliconsoft.com). Palp and leg measurements are given as follows: total (femur, patella, tibia, metatarsus, tarsus). All measurements are given in millimetres.

Abbreviations: a - apical, ALE - anterior lateral eyes, AME - anterior median eyes, $b$ - basal (proximal), d - dorsal, EWH - Encyclopedia of World History, $\mathrm{p}$ - prolateral, pd — prodorsal, PLE - posterior lateral eyes, PLS - posterior lateral spinnerets, $\mathrm{PME}$ - posterior median eyes, PMS — posterior median spinnerets, PTC - paired tarsal claws, pv proventral, $\mathrm{r}$ - retrolateral, $\mathrm{rd}$ - retrodorsal, rv retroventral, v — ventral, WSC — World Spider Catalog. 


\section{Taxonomic survey}

Family Cyrtaucheniidae Simon, 1889 Subfamily Aporoptychinae Simon, 1889

NOTES. The Aporoptychinae is considered to comprise a majority of the cyrtaucheniid genera - 6-7 of the 11-12, depending on the different points of view; see Raven [1985] and Bond et al. [2012]. According to the WSC [2018], the representatives of the subfamily are distributed in South America (most genera) and Africa (Acontius). Currently, the monophyletic status of both Cyrtaucheniidae and Aporoptychinae is debated; see Bond \& Opell [2002]; Hedin \& Bond [2006]; Bond et al. [2012]; Garrison et al. [2016]; Wheeler et al. [2017].

Genus Acontius Karsch, 1879

TYPE SPECIES. Acontius hartmanni Karsch, 1879 (Central Africa), by monotypy.

COMPOSITION. In view of the data presented here, the genus includes 12 named species: $\sigma^{7} \mathrm{~A}$. aculeatus (Simon, 1889) (Equatorial Guinea); $\sigma^{7}+$ A. africanus (Simon, 1889) (Angola, Equatorial Guinea); 9 A. australis (Simon, 1886) (Argentina); $\bigcirc$ A hartmanni Karsch, 1879 (Gabon to Congo); + A. humiliceps (Simon, 1907) (Equatorial Guinea); $\sigma^{\top}+$ A. kiriba sp.n. (Burundi); + A. lamottei (Dresco, 1972) (Ivory Coast); $\sigma^{T}$ A. lawrencei Roewer, 1953 (Congo); $\bigcirc^{T}$ A. lesserti Roewer, 1953 (Congo); O A. machadoi (Lawrence, 1938) (Congo); $\sigma^{\top}+A$. nimba sp.n. (Guinea) and $\sigma^{\top} A$. stercoricola (Denis, 1955) (Guinea).

DISTRIBUTION. Eleven species are distributed in the west and central regions of Africa, while A australis is known only from the holotype female collected from Argentina (according to Raven [1985] the latter record is based on an erroneous label).

NOTES. WSC [2018] lists Acontius africanus as distributed in West Africa and Congo. However, the species was described by Simon [1889] from Northern Angola (Landana $=$ the recent Cacongo in Cabinda Province) and was later registered for Fernando Poo in Equatorial Guinea [Simon, 1907]. According to the WSC [2018], A. hartmanni is also shown to be distributed in West Africa. However, since the original description [Karsch, 1879], this species has been known only from the type locality, "Loango Küste" (the seashore historical area situated between the recent southwestern Gabon and north-western Congo) [see EWH, 2008]. Hence, the known range of $A$. africanus and $A$. hartmanni is entirely limited to Central African countries and does not enter West Africa.

\section{Acontius nimba sp.n.}

Figs 1-15

TYPES: holotype $\sigma^{7}$ (SMF), GUINEA: Nzérékoré Region, Nimba Mt Range, Mt Nimba, November 1957, M. Lamotte; paratypes: $3 \sigma^{\top} \sigma^{\top}, 4 \circ+$ (SMF), collected together with holotype; $1 \sigma^{\top}, 5+0$
(SMF), same data but December 1957; $2 \sigma^{\top} \sigma^{\top}, 2$, 29 (SMNH), same area, November 2016, V. Kravchenko and G. Müller.

ETYMOLOGY. The specific epithet is a toponym referring to the type locality, Mt. Nimba.

DIAGNOSIS. Acontius nimba sp.n. resembles the Guinean $A$. stercoricola in having a similar structure of the male palp; it also shares with the Central African $A$. hartmanni the same type of dorsal abdominal pattern (Figs 6-8, 10; cf. Denis, 1955, figs 2, 3; Raven, 1985, fig. 207). However, males of $A$. nimba sp.n. differ from the only known male of $A$. stercoricola in possessing a considerably longer embolus and unmodified metatarsus I (which are respectively shorter and bent in the latter species; Figs 5-8, cf. Denis, 1955, figs 1-3). Females of $A$. nimba sp.n. can be distinguished from the holotype of $A$. hartmanni in the shape of the spermathecae (with racemose receptacles in the former species, and with two widely spaced receptacles in the latter one; Fig. 14, cf. Raven, 1985, fig. 208).

MALE (holotype). Body length 12.80. Habitus as shown in Fig. 1. Colouration: carapace, palpal femur, femora I-II, patella and tibia I dark reddish brown; other leg segments reddish brown, lightening from femora to tarsi; eye tubercle blackish brown; chelicerae deep brown; sternum, labium and maxillae reddish brown; coxae yellowish brown; abdomen dorsally chestnut brown with lighter yellowish pattern consisting of several short transverse fasciae; ventral surface of abdomen and spinnerets dark yellow.

Prosoma as in Figs 2 and 4. Carapace 5.76 long, 4.36. Clypeus and eye tubercle as shown in Fig. 3. Eye diameters and interspaces: AME 0.17(0.27), ALE 0.27, PLE 0.20, PME 0.10, AME-AME 0.18(0.08), ALEAME 0.10(0.05), ALE-PLE 0.08, PLE-PME 0.05, PME-PME 0.69. Chelicerae with rastellum composed of $c a .30$ spikes in front of fang base. Each cheliceral furrow with 6 promarginal teeth and about 15 very small mesobasal denticles. Labium 1.07 long, 0.86 wide, without cuspules. Sternum 2.98 long, 2.17 wide. Sternal sigilla small submarginal. Maxillae with $c a .10$ small cuspules confined to anterior part of maxillary heel. Serrula not evident (under light microscope at magnification $150 \mathrm{x}$ ).

Palp and legs measurements: palp - 7.02 (2.67, 1.26, 1.89, -, 1.22); I - 16.44 (4.32, 2.36, 3.67, 3.76, 2.33); II - $14.29(3.71,2.12,3.19,3.22,2.05)$; III $10.56(3.00,1.61,1.52,2.72,1.71):$ IV -15.54 (4.34, $2.08,3.58,3.67,1.87)$.

Palp and leg structures. Tibia and metatarsus I as shown in Fig. 5. Spines (palpal femur, patella IV, tarsi I-IV and cymbium aspinose). Palp: patella p1; tibia pv3. Leg I: femur d4, pd2a; patella p2(3), v6; tibia p4; v19, metatarsus v2. Leg II: femur d4(5), pd2a; patella p2, v3; tibia p3, v15(16); metatarsus v10. Leg III: femur d5(6), pd3(4), rd3; patella d3a, p10(11); tibia d2, p2, r2, v7; metatarsus d1, p4, r4(5), v5. Leg IV: femur d10(11); tibia r2, v8(10); metatarsus r2, v7(8). Metatarsal preening combs absent. Scopula thin and short (as long as $0.25-0.35$ width of corresponding leg segment), but relatively dense; distal on metatarsi I and 

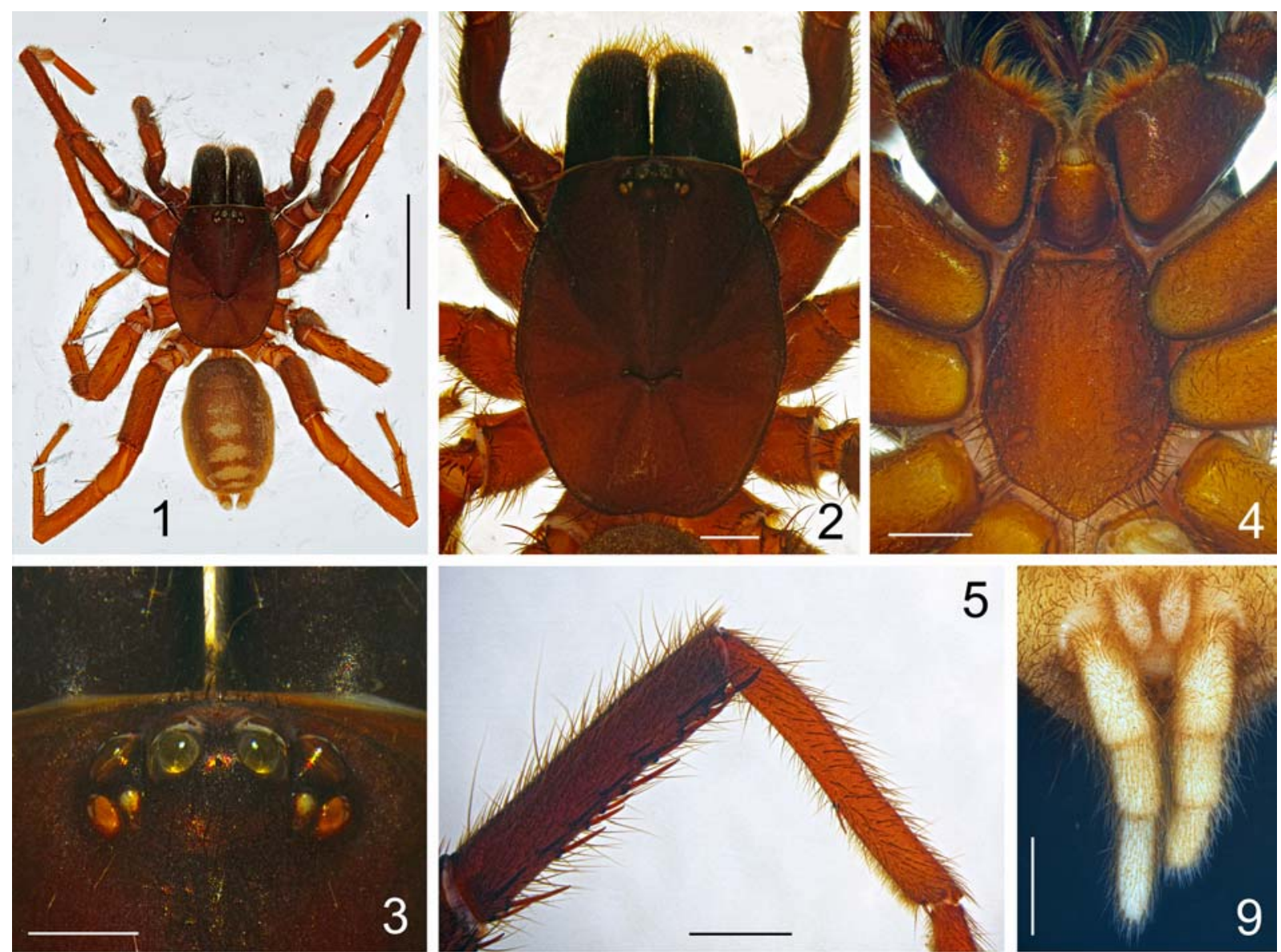

5
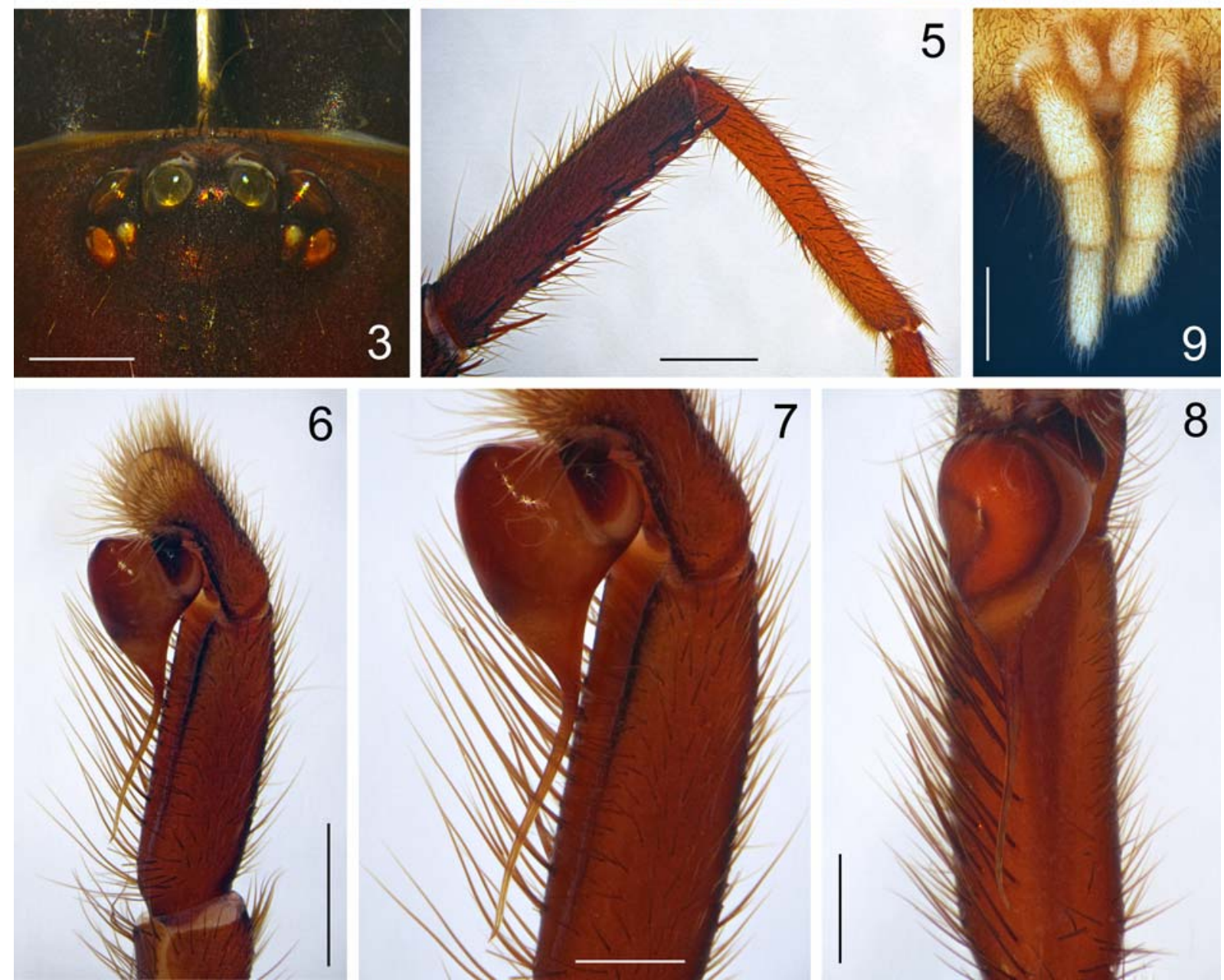

6
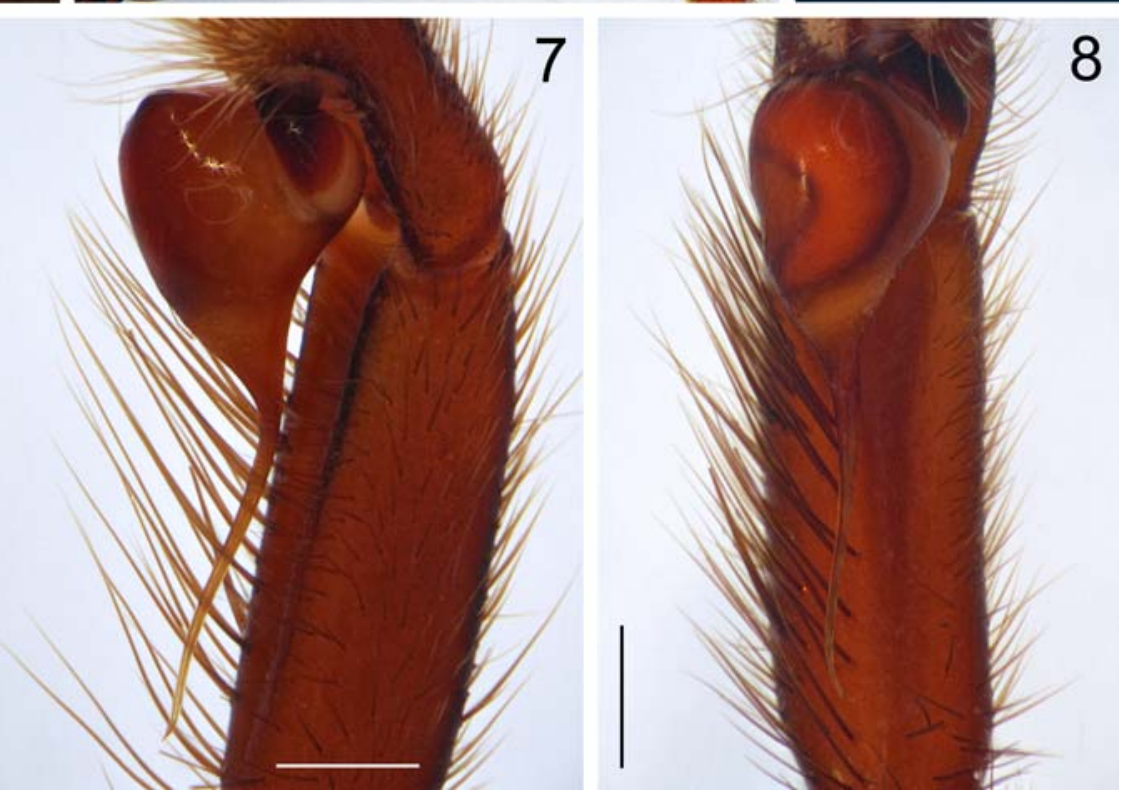

Figs. 1-9. Acontius nimba sp.n., holotype male (SMF): 1 - habitus, dorsal view; 2 - prosoma, dorsal; 3 - clypeus and eye tubercle, dorsal; 4 - prosoma, ventral; 5 - tibia and metatarsus I, prolateral; 6 - distal palpal segments showing bulb and embolus, retrolateral; 7 bulb and embolus close up, retrolateral; 8 - same, ventral; 9 - spinnerets, ventral. Scale bars for Fig. 1 - 5.0 mm, for Figs 2 , 4-6 - 1.0 $\mathrm{mm}$, for Figs 3, 7-9 - $0.5 \mathrm{~mm}$.

Рис. 1-9. Acontius nimba sp.n., самец голотип (SMF): 1 - общий вид сверху; 2 - просома сверху; 3 - наличник и глазной бугорок сверху; 4 - просома снизу; 5 - голень и предлапка I сбоку (снутри); 6 - дистальные сегменты педипальпы, бульбус и эмболюс сбоку (снаружи); 7 - бульбус и эмболюс при большем увеличении сбоку (снаружи); 8 - то же, снизу; 9 - паутинные бородавки снизу. Масштаб для рис. $1-5,0$ мм, для 2, 4-6-1,0 мм, для 3, 7-9 - 0,5 мм. 

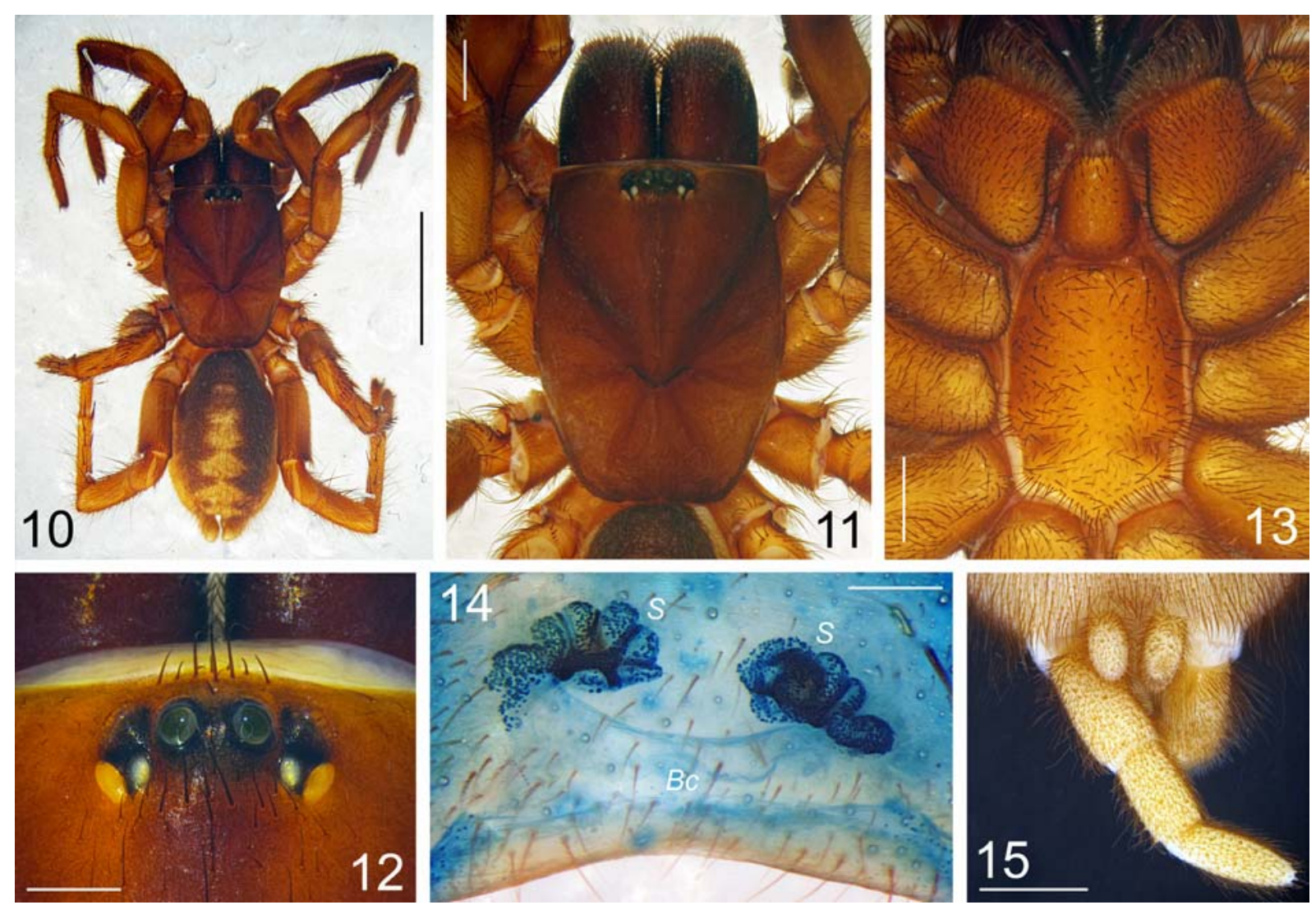

Figs. 10-15. Acontius nimba sp.n., paratype female (SMF): 10 - habitus, dorsal view; 11 - prosoma, dorsal; 12 - clypeus and eye tubercle, dorsal; 13 - prosoma, ventral; 14 - spermathecae, dorsal; 15 - pinnerets, ventral. Scale bars for Fig. 10 - 5.0 mm, For Figs 11, 13, $15-1.0 \mathrm{~mm}$, for Fig. $12-0.5 \mathrm{~mm}$, for Fig. $14-0.25 \mathrm{~mm}$. Abbreviations: Bc - Bursa copulatrix, $S-$ spermatheca.

Рис. 10-15. Acontius nimba sp.n., самка паратип (SMF): 10 - общий вид сверху; 11 - просома сверху; 12 - наличник и глазной бугорок сверху; 13 - просома снизу; 14 - сперматеки сверху (изнутри); 15 - паутинные бородавки снизу. Масштаб для рис. $10-5,0$ мм, для $11,13,15-1,0$ мм, для $12-0,5$ мм, для $14-0,25$ мм. Сокращения: Bc-Bursa copulatrix, $S-$ сперматека.

II, entire on tarsi I and II; elsewhere absent. Trichobothria: 2 rows of $10-11$ in each row on tibiae, $12-16$ on metatarsi, 11-14 on tarsi, 8-9 on cymbium. PTC I-II, and III-IV with 6, and 5-6 teeth in each row, respectively. Unpaired tarsal claw small and sharply curved.

Palp. Palp with moderately short subcylindrical tibia and relatively long cymbium (Fig 6). Tibia 2.5 times longer than wide, venter of tibia with longitudinal groove. Bulb (tegular and embolic parts) as long as tibia; embolic part filamentous, 1.5 times longer than tegular part (Figs 7-8).

Spinnerets (Fig. 9). PMS: length 0.67; diameter 0.29 . PLS: maximal diameter 0.54 ; length of basal, medial and apical segments $1.14,0.72,1.02$, respectively; total length 2.88; apical segment digitiform.

FEMALE (paratype). Body length 17.40. Habitus as shown in Fig. 10. Colour as in male.

Prosoma as in Figs 11 and 13. Carapace 6.36 long, 4.55 wide. Clypeus and eye tubercle as shown in Fig. 12. Eye diameters and interspaces: AME 0.22(0.30), ALE 0.34, PLE 0.25, PME 0.17, AME-AME 0.20(0.12), ALE-AME 0.17(0.13), ALE-PLE 0.07, PLE-PME 0.05, PME-PME 0.70. Chelicerae with weak rastellum composed of 35-40 spikes in front of fang base. Each furrow with 8-9 teeth on promargin and 14-15 small mesobasal denticles arranged in two short median rows. Labium 1.35 long, 1.04 wide, without cuspules. Sternum 3.33 long, 2.31 wide. Sternal sigilla small submarginal. Maxillae with $c a$. 13-15 small cuspules confined to anterior part of maxillary heel. Serrula indiscernible.

Palp and legs measurements: palp - 8.69 (3.17, $1.32,1.98,-, 2.02)$; I -15.04 (4.34, 2.62, 3.41, 2.78, 1.89); II - 12.91 (3.82, 2.19, 2.58, 2.46, 1.86); III $9.96(2.96,1.71,1.51,2.14,1.64)$ IV -15.17 (4.47, $2.22,3.31,3.34,1.83)$.

Palp and leg structures. Spines (all femora with 1-3 basodorsal spines and 3-4 median bristles; patellae I, II and IV, and tarsi I-IV aspinose). Palp: d2(3); patella pd1(2), pv1; tibia p2, v8; tarsus v3(5). Leg I: tibia v5, metatarsus v5(7). Leg II: tibia v5; metatarsus v11. Leg III: patella pd 25, r1; tibia d1(2), p3, r2, v7(8); metatarsus pd4(6), rd4(5), v6(7). Leg IV: tibia rd2, v7; metatarsus rd2; v10(11). Metatarsal preening combs absent. Scopula: moderately short (as long as 0.250.35 width of corresponding leg segment) and dense; 
entire and distal on metatarsus I and and II; entire on palpal tarsus and tarsi I and II; elsewhere absent. Trichobothria: 2 rows of $8-12$ in each row on tibiae, $11-$ 16 on metatarsi, $10-14$ on tarsi I-IV, 10 on palpal tarsus. PTC I-II with 5-6, PTC III with 5 teeth in each row. PTC IV with 4-5 teeth in outer row and 5 teeth in inner row. Unpaired tarsal claw small and sharply curved. Palpal claw with 4 prolateral teeth.

Spermathecae (Fig. 14). Bursa copulatrix $(B c)$ without pore glands; bases of spermathecae 2 times longer than wide; spiraled spermathecae $(S)$ spaced apart by about 3 their diameters.

Spinnerets (Fig. 15). PMS: 0.77 long; 0.39 wide. PLS: maximal width 0.65 ; length of basal, medial and apical segments $1.16,0.91,1.13$, respectively; total length 3.20; apical segment digitiform.

VARIATION. Length of the carapace varies in males from 4.72 to 5.89 , in females from 4.87 to 6.44 . Within the studied series, no significant differences in shape and colour of the dorsal abdominal pattern are evident. cality.

DISTRIBUTION. Known only from the type lo-

\section{Acontius kiriba sp.n.}

Figs 16-30.

MATERIAL EXAMINED: BURUNDI: holotype $\sigma^{7}$, National Park Kiriba, Rwegura, 10.01.2009, B. Nzigidahera leg. (MRAC 226884); 1 \% paratype, same data but 10.11.2008 (MRAC 226868).

ETYMOLOGY. The specific epithet is a toponym referring to the type locality, National Park Kiriba.

DIAGNOSIS. The holotype male of Acontius kiriba sp.n. resembles the Eastern Congolese $A$. machadoi in possessing a somewhat similar structure of the male palp; however, it differs from the latter, as well as from other species of Acontius in having a unique basoventral horn-like process on the bulb (Figs 21-23; cf. Lessert, 1938, fig. 6; Roewer, 1953, figs 12D, 13D; Denis, 1955, figs 2, 3). The holotype female of $A$. kiriba sp.n. can be distinguished from females of $A$. australis and $A$. hartmanni by the shape of the spermathecae (which are subdivided apically in the former, and divided basally in the two latter species; Fig. 29, cf. Schiapelli, Gerschman, 1962, pl. IV, fig. 1; Raven, fig. 208). It differs from the two remaining species known only from females, $A$. humiliceps and $A$. lamottei, in having a better developed cheliceral rastellum consisting of 30-40 spikes vs. $12-13$ and a few spikes in the former and latter species respectively; see Simon [1907], Dresco [1972].

MALE (holotype). Body length 12.50. Habitus as shown in Fig. 16. Colouration: carapace, palps, patella and tibia I medium to light chestnut brown; other leg segments medium to light ochreous brown; chelicerae and eye tubercle dark brown; coxae, maxillae and book lungs yellowish brown; labium and sternum anteriorly and laterally light chestnut brown; other parts of sternum brownish yellow with orange tint; abdomen dorsally coffee brown with small transverse light ochreous brown spot in anterior quarter and with a pair of smaller similarly coloured marks laterally; ventral surface of abdomen (except several small transverse brown marks) and spinnerets pale brownish yellow.

Prosoma as in Figs 17 and 19. Carapace 5.34 long, 4.42. Clypeus and eye tubercle as in Fig. 18. Eye diameters and interspaces: AME 0.22(0.28), ALE 0.26, PLE 0.24, PME 0.21, AME-AME 0.14(0.08), ALEAME 0.15(0.12), ALE-PLE 0.10, PLE-PME 0.04, PME-PME 0.54. Chelicerae with weak rastellum composed of 30-40 spikes in front of fang base. Each cheliceral furrow with 5 promarginal teeth and approximately 15 small mesobasal denticles. Labium 0.87 long, 0.85 wide, without cuspules. Sternum 2.95 long, 2.26 wide. Sternal sigilla small submarginal. Maxillae with 8-9 small cone cuspules confined to heel. Serrula not evident (under light microscope at magnification 150x).

Palp and legs measurements: palp -8.44 (3.11, 1.48, 2.58, -, 1.27); I - 17.41 (4.73, 2.44, 4.06, 3.94, 2.24); II - 16.07 (4.39, 2.28, 3.57, 3.61, 2.22); III 12.46 (3.64, 1.71, 2.04, 3.09, 1.98): IV - 17.14 (4.42, $1.90,4.29,4.24,2.29)$.

Palp and leg structures. Tibia and metatarsus I as shown in Fig. 20. Spines (palp, patella IV, and tarsi IIV aspinose). Leg I: femur d1(2)b; patella pv1; tibia p5(6), r6; v14(16), metatarsus v9. Leg II: femur d4b, pd2; patella p1; tibia p4(5), v10; metatarsus p2, v12(16). Leg III: femur d4(5)b, pd1(2), rd1(2); patella p6(7), r2; tibia d2, p2(3), r2, v7; metatarsus pd3(5), rd4(5), v9(10). Leg IV: femur d7(8); tibia r2, v9; metatarsus r4, v9(10). Metatarsal preening combs absent. Scopula thin, as long as $0.25-0.35$ width of corresponding leg segment and very moderately dense; distal on metatarsi I and II, entire on tarsi I and II; elsewhere absent. Trichobothria: 2 rows of 7-9 in each row on tibiae, 10-16 on metatarsi, 10-13 on tarsi, 8-9 on cymbium. Number of teeth in inner and outer margin of PTC, respectively: I - 7/10-11; II - 6-7/9-10; III - 7-8/7-8; IV - 8/ 8. Unpaired tarsal claw small and sharply curved.

Palp. Tibia relatively thin and long, 4 times longer than wide, with ventral groove in anterior $2 / 3$ (Fig. 21). Bulb subtriangular in lateral view, short, 2 times shorter than tibia; short; embolic part 2 times shorter than tegular one, dorso-basal part of tegulum with knob-like outgrowth (Ko) (Figs 22-23).

Spinnerets (Fig. 24). PMS: 0.82 long, 0.37 wide. PLS: maximal width 0.65 ; length of basal, medial and apical segments $1.13,0.85,1.03$, respectively; total length 3.01; apical segment digitiform.

FEMALE (paratype). Body length 15.40. Habitus as shown in Fig. 25. Colour as in male, but thoracic portion of carapace, palps and legs I-IV lighter, medium to light yellowish orange.

Prosoma as in Figs 26 and 28. Carapace 5.95 long, 4.56 wide. Clypeus and eye tubercle as shown in Fig. 27. Eye diameters and interspaces: AME 0.24(0.32), ALE 0.37, PLE 0.34, PME 0.26, AME-AME 0.15(0.07), ALE-AME 0.17(0.13), ALE-PLE 0.08, 

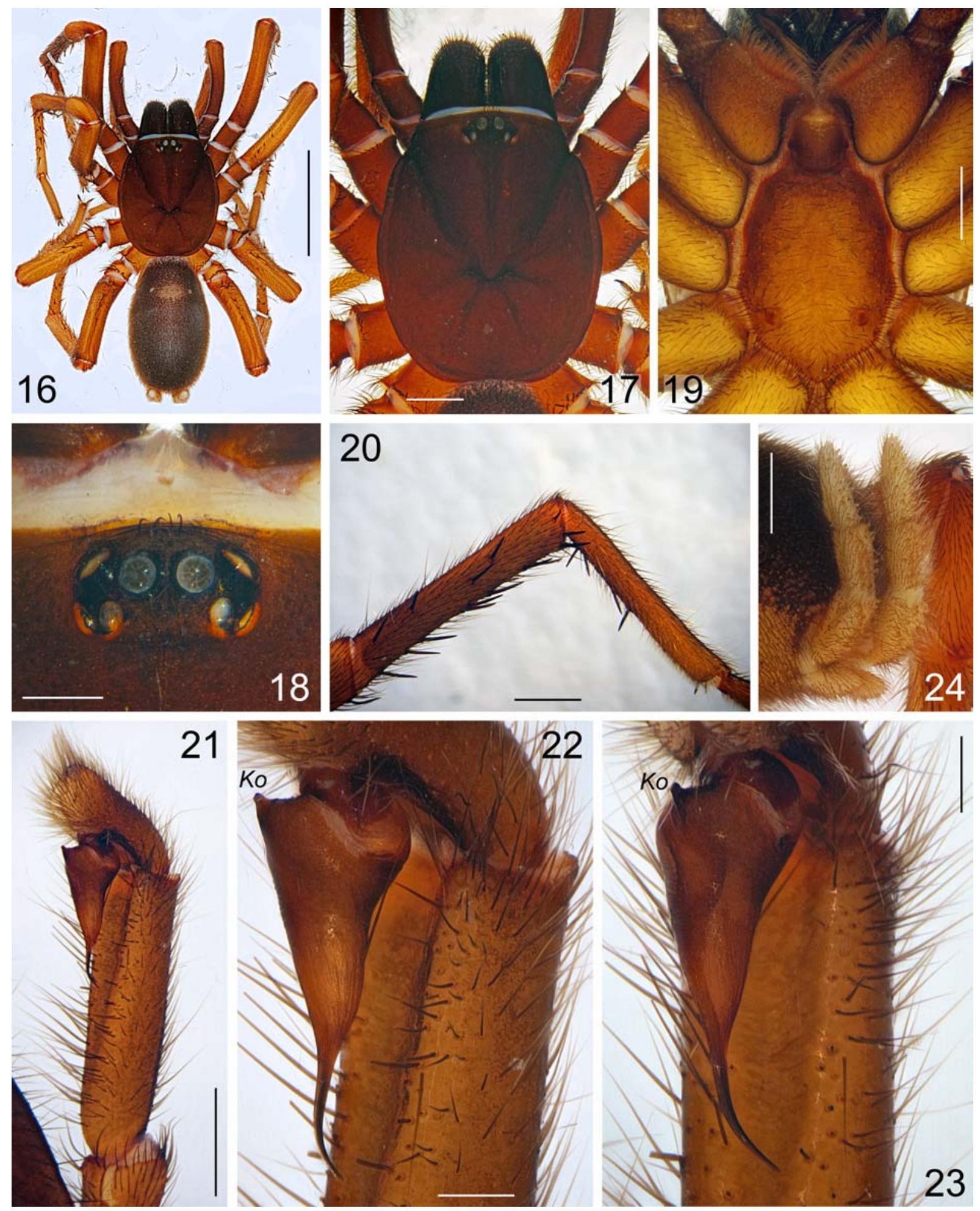

Figs. 16-24. Acontius kiriba sp.n., holotype male (MRAC 226884): 16 - habitus, dorsal view; 17 - prosoma, dorsal; 18 - clypeus and eye tubercle, dorsal; 19 - prosoma, ventral; 20 - tibia and metatarsus I, prolateral; 21 - distal palpal segments showing bulb and embolus, retrolateral; 22 - palpal organ, retrolateral; 23 - palpal organ, ventral; 24 - spinnerets, lateral. Scale bars for Fig. $16-5.0$ mm, for Figs 17, 19-21 - 1.0 mm, for Figs 18, 22-24 - 0.5 mm. Abbreviations: Ko - knob-like outgrowth.

Рис. 16-24. Acontius kiriba sp.n., самец голотип (MRAC 226884): 16 - общий вид сверху; 17 - просома сверху; 18 наличник и глазной бугорок сверху; 19 - просома снизу; 20 - голень и предлапка I сбоку (снутри); 21 - дистальные сегменты педипальпы, бульбус и эмболюс сбоку (снаружи); 22 - бульбус и эмболюс при большем увеличении сбоку (снаружи); 23 - то же, снизу; 24 - паутинные бородавки снизу. Масштаб для рис. 16 - 5.0 мм, для 17, 19-21 - 1,0 мм, для 18, $22-24-0,5$ мм. 

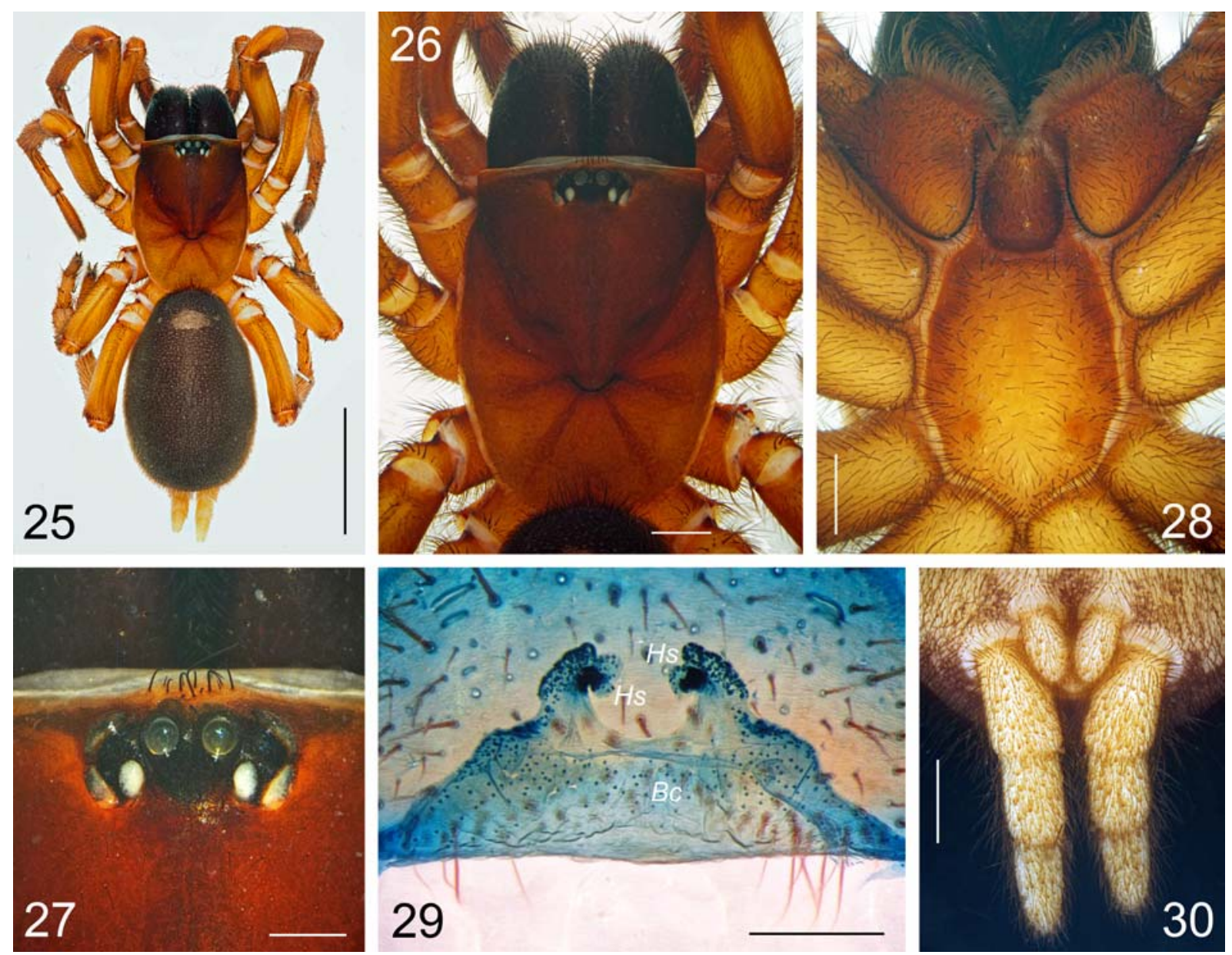

Figs. 25-30. Acontius kiriba sp.n., paratype female (MRAC 226868): 25 - habitus, dorsal view; 26 — prosoma, dorsal; 27 clypeus and eye tubercle, dorsal; 28 - prosoma, ventral; 29 - spermathecae, dorsal; 30 - spinnerets, ventral. Scale bars for Fig. 25 $5.0 \mathrm{~mm}$, For Figs 26, 28, 30-1.0 mm, for Fig. $27-0.5 \mathrm{~mm}$, for Fig. $29-0.25 \mathrm{~mm}$. Abbreviations: Bc - Bursa copulatrix, Hs - head of spermatheca.

Pис. 25-30. Acontius nimba sp.n., самка паратип (MRAC 226868): 25 - общий вид сверху; 26 - просома сверху; 27 наличник и глазной бугорок сверху; 28 - просома снизу; 29 - сперматеки сверху (изнутри); 30 - паутинные бородавки снизу. Масштаб для рис. $25-5,0$ мм, для 26, 28, $30-1,0$ мм, для $27-0,5$ мм, для $29-0,25$ мм. Сокращения: Bc - Bursa copulatrix, $H s$ - головка сперматеки.

PLE-PME 0.05, PME-PME 0.56. Cheliceral rastellum as in male. Each cheliceral furrow with 5-6 promarginal teeth and 13-15 small mesobasal denticles. Labium 1.23 long, 1.09 wide, without cuspules. Sternum 3.28 long, 2.45 wide. Sternal sigilla as in male. Maxillae with $c a$. 10 cuspules each. Serrula indiscernible.

Palp and legs measurements: palp -8.88 (3.05, $1.49,2.08,-, 2.26)$; I - 16.00 (4.66, 2.46, 3.66, 3.07, $2.15)$; II - $14.13(4.12,2.23,3.03,2.74,2.01)$; III $11.24(3.76,1.72,1.76,2.41,1.59)$ : IV -15.76 (4.54, 2.06, 3.96, 3.42, 1.78).

Palp and leg structures. Spines (femora I-IV with 1-2 thin basodorsal spines and 3-6 medial bristles; palpal femur only with bristles; palpal patella and patellae I, II and IV, tibiae I-II and tarsi I-IV aspinose). Palp: tibia v5; tarsus v2b. Leg I: metatarsus v5. Leg II: metatarsus v7. Leg III: patella p6, r1; tibia d2, p1, r2, v7; metatarsus pd2, rd4, p2; v7. Leg IV: femur d12(15)a; tibia r2, v7; metatarsus p2, r2; v7. Metatarsal preening combs absent. Scopula as in male; distal on metatarsi I and II; entire on tarsus I and palpal tarsus; widely divided on tarsus II; elsewhere absent. Trichobothria: 2 rows of 9-10 in each row on tibiae, 14-16 on metatarsi, 11-13 on tarsi I-IV, 9 on palpal tarsus. PTC I-II, III, and IV with 10-11, 6-7 and 5-7 teeth in each row, respectively. Unpaired tarsal claw small and sharply curved. Palpal claw with 5 prolateral teeth.

Spermathecae as in Fig. 29. Bursa copulatrix $(B c)$ with evenly distributed pore glands; spermathecae conical with wide bases ( $\mathrm{Sb}$ ) separated by about one diameter; mesal parts of bases without pore glands, lateral parts with dense pore glands; spermathecae converging; anterior part of spermatheca with elongate heads $(H s)$ attached mesally, heads separated by 1.5 times their diameter. 
Spinnerets as shown in Fig. 30. PMS: 0.86 long; 0.44 wide. PLS: maximal diameter 0.78 ; length of bas$\mathrm{al}$, medial and apical segments $1.39,1.04,1.18$, respectively; total length 3.61; apical segment digitiform. ity.

DISTRIBUTION. Known only from the type local-

\section{Acknowledgements}

I am thankful to Peter Jäger and Julia Altmann (SMF), Rudi Jocqué and Arnaud Henrard (MRAC) for the possibility to examine the cyrtaucheniid specimens deposited in these collections. The English of the final draft was kindly checked and edited by Sarah Crews (Oakland, California, USA). This study was partially supported by the Ministry of Absorption, Israel.

\section{References}

Bond J.E., Hedin M. 2006. A total evidence assessment of the phylogeny of North American euctenizine trapdoor spiders (Araneae, Mygalomorphae, Cyrtaucheniidae) using Bayesian inference // Molecular Phylogenetics and Evolution. Vol.41. P.70-85.

Bond J.E., Hendrixson B.E., Hamilton C.A., Hedin M. 2012b. A reconsideration of the classification of the spider infraorder Mygalomorphae (Arachnida: Araneae) based on three nuclear genes and morphology // PLoS ONE. Vol.7. No.6. e38753.

Bond J.E., Opel B.D. 2002. Phylogeny and taxonomy of the genera of south-western North American Euctenizinae trapdoor spiders and their relatives (Araneae: Mygalomorphae, Cyrtaucheniidae) // Zoological Journal of the Linnean Society. Vol.136. P.487-534.

Denis J. 1955. Speologica africana: quelques araignées cavernicoles de Guinée française // Bulletin de l'Institut Fondamental d'Afrique Noire. Vol.17(A). P.1024-1033.

Dresco E. 1972. Études sur les mygales. Sur deux mygales terricoles de Côte-d'Ivoire, description de Aporoptychus lamottei, sp. nov. (Fam. Ctenizidae, s. f. Ctenizinae) // Bulletin de 1'Institut Fondamental d'Afrique Noire. Vol.34(A). P.544-549.

Encyclopedia of World History 2008. / Ackermann M.E. et al. (eds.). Vol.III. New York: Infobase Publ.. 440 p.
Garrison N.L., Rodriguez J., Agnarsson I., Coddington J.A., Griswold C.E., Hamilton C.A., Hedin M., Kocot K.M., Ledford J.M., Bond J.E. 2016. Spider phylogenomics: untangling the Spider Tree of Life // PeerJ. Vol.4. e1719.

Hedin M., Bond J.E. 2006. Molecular phylogenetics of the spider infraorder Mygalomorphae using nuclear rRNA genes (18S and 28S): Conflict and agreement with the current system of classification // Molecular Phylogenetics and Evolution. Vol.41. P.454-471.

Lessert R. 1938. Araignées du Congo belge (Première partie) // Revue de Zoologie et de Botanique Africaines. T.30. P.424457.

Raven R.J. 1985. The spider infraorder Mygalomorphae (Araneae): cladistics and systematics // Bulletin of the American Museum of Natural History. Vol.182. P.1-180.

Roewer C.F. 1953. Araneae-Orthognatha (Arachnoidae) // Exploration du Parc National de l'Upemba, Mission G. F. de Witte. Vol.22. P.1-80.

Schiapelli R.D., Gerschman de Pikelin B.S. 1962. Importancia de las espermatecas en la sistemática de las arañas del suborden Mygalomorphae (Araneae) // Physis, Revista de la Sociedad Argentina de Ciencias Naturales. Ser.C. Vol.23. P.69-75.

Simon E. 1889. Descriptions d'espèces africaines nouvelles de la famille des Aviculariidae // Actes de la Société Linnéenne de Bordeaux. Vol.42. P.405-415.

Simon E. 1903. Arachnides de la Guinée espagnole // Memorias de la Real Sociedad Española de Historia Natural Vol.1. No.3. P.65-124.

Simon E. 1907. Arachnides recueillis par L. Fea sur la côte occidentale d'Afrique. 1re partie // Annali del Museo Civico di Storia Naturale di Genova. Ser.3 Vol.3. P.218-323.

Wheeler W.C., Coddington J.A., Crowley, L.M. Dimitrov D., Goloboff P.A., Griswold C.E., Hormiga G., Prendini L., Ramírez M.J., Sierwald P., Almeida-Silva L.M., Álvarez-Padilla F., Arnedo M.A., Benavides L.R., Benjamin S.P., Bond J.E., Grismado C.J., Hasan E., Hedin M., Izquierdo M.A., Labarque F.M., Ledford J., Lopardo L., Maddison W.P., Miller J.A., Piacentini L.N., Platnick N.I., Polotow D., Silva-Dávila D., Scharff N., Szûts T., Ubick D., Vink C.J., Wood H.M. \& Zhang J.X. 2017. The spider tree of life: phylogeny of Araneae based on target-gene analyses from an extensive taxon sampling // Cladistics. Vol.33. No.6. P.576-616.

World Spider Catalog. 2018. World Spider Catalog. Available from: http://wsc.nmbe.ch, version 19.5 (accessed 18.07.2018).

Responsible editor Yu.M. Marusik 